\title{
離散系シミュレーションを活用した 多品種多段階かんばん方式の運用手法*
}

\author{
光行恵 司*1, 小島史 $*^{* 1}$, 道場広 貢*2 \\ 福田好朗*3, 荒井栄司*4
}

\section{Operation Method for Multi-Types and Multi-Stages Kanban System Using Discrete Event Simulation}

\author{
Keiji MITSUYUKI*5, Fumio KOJIMA, Hirotsugu DOUBA, \\ Yoshiro FUKUDA and Eiji ARAI \\ ${ }^{* 5}$ Production Engineering Department, DENSO CORPORATION, \\ 1-1 Showa-cho, Kariya-shi, Aichi, 448-8661 Japan
}

\begin{abstract}
Many studies have been done to optimize the Kanban system as production control system. However, most of them can be effective on only limited conditions. Therefore, these studies have difficulties to be applied in practice. The purpose of this study is to propose the practical method to operate Multi-types and Multi-stages Kanban system using discrete event simulation. The method sets the number of Kanbans much larger than the estimated number on the simulation model. From the simulation result, the surplus inventory is found. By subtracting the surplus inventory from the maximum inventory, the necessary number of Kanbans and the average of inventory are determined. Also the changeover time is calculated from the simulation result. The performance of Kanban system can be measured through the average of inventory and the changeover time. The best plan to operate Kanban system is selected among many alternatives based on that performance. To confirm the effectiveness of the method, an actual test case is tried out.
\end{abstract}

Key Words: Kanban, Simulation, Production Control, Manufacturing System

\section{1. 踫 害}

複数の多段階のラインからなる加工・組立生産シ ステムにおいて, 多品種変量生産の頃向か強まってき ている. このような時代に, 在庫を圧維し, 品種切り 替えに即応できる生産体制を構筑, 運営していくこと はますます重要となってきている. そのため, 多段階 の加工・組立生産システムでは, 在庫を適正にコント ロールし, 品種の切り替え指示が容易な, かんばん方 式に基づく生産管理が多くの企業で導入されてきてい る.

かんばんの運用手法については, 生産量やロット サイズに基づくかんばん枚数やかんばんの指示先の設 定などについて多くの研究が行われており(2), シミ ユレーションを活用した研究も実施されている. 例え ば, 高橋らは，多段階単品種の生産システムについ て, 数学的モデルを使ったシミュレーションを用いて,

* 原稿受付 2003 年 6 月 30 日.

*1 正員, (株) デンソー(\$ 448-8661 刈谷市昭和町 1-1).

*2 (株) デンソー.

*3 正員, 法政大学工学部 (昰185-8484 小金井市梶野町 3-7-2).

*4 正員, 大阪大学工学部( 565-0871 吹田市山田丘 2-1)

E-mail : mitsu@prd.denso.co.jp
需要の待ち時間を一定以下に抑えながら, 在庫量を最 小化するためのかんばん枚数を求めるアルゴリズムを 提案している. 柳川らせは, 部品使用量とリードタイ ムのばらつきを考虑した 1 段階定量引き取りかんばん 方式についてシミュレーションモデルを用意し, 在庫 費用と引き取り費用の総和を最小化するかんばん枚数 とコンテナ容量の決定方法を提案している. 村木ら(5) は, 多段階の生産システムにおいて, かんばんの行き 先を変化させることにより, 在庫スペースを適切に調 整できる階層型かんばん制铄生産システムの提案をし ている.

これらの研究では，単品種の扱いであったり，1段 階であったり, 引き取りかんばんの形式に限ったり, かんばんの行き先のみを変更させたり，ある制約の下 で最適な運用条件を求めることに研究の力点を置いて いる. しかしながら，実際の運用においては，前提と された制約そのものが，全て変数となる可能性があり, このようなさまざまな考虑すべき条件に応じて, 制約 を伴った最適化の手法を選択しながら運用条件を決定 することは現実的に困難である. 
そこで本研究では, 最適化を追求するのではなく, 与えられた生産条件に対して, 多面的にかんばん運用 条件を検討できる環境を整えることが重要であると考 え, シミュレーションを活用したかんばん運用手法を 提案する.

まず，かんばん方式に基づく多品種多段階生産シ ステムの構成要素とその挙動を明確化しモデル化を行 う. そのモデルに基づき, かんばん生産システムの運 用条件決定上の問題点を明らかにした上で, シミュレ ーションを使ったかんばん生産システムの評価手法を 提案する. 提案した手法の有效性検証のため, 多品種 多段階生産システムにおけるかんばん方式の運用条件 の検討を行う.

\section{2 多品亚多段睹かんばん生産システムの 这用来件決定上の间昌}

$2 \cdot 1$ 対系生库システムの前提条件 かんばん 方式を用いている生産システムを物流と生産制御の 観点から分析を行った. 一般に加工, 組立生産シス テムでは, 単一の生産ラインのみで生産活動が行わ れることはまれである. 本研究で対象とした生産シ ステムは次のような前提条件を有する.

\section{1) ワーク}

多品種量産製品とする.

\section{2) ライン}

多品種のワークを同一のラインで加工・組立する ことができるが, 品種の切り替えには品種の切り替 え時間が発生する場合もある.

3）生産システム

工程順に従ってラインが直列に多段階連なってい る. ただし, ある工程は複数の並列のラインが存在 する場合もある.

4) 需要

ある対象期間において，それぞれの品種毎にバラ ツキは有るものの平均としては一定の需要が有るも のとする.

\section{$2 \cdot 2$ かんばんの可用モデル かんばん生産シ} ステムの運用構造は, 図 1 に示すようにモデル化で きる゙。ノドは, ワークとかんばんの状態を表し， 矢印はそれぞれの状態遷移を表す。

\section{1) 在庫}

収容数分の完成品ワークとかんばんが，一体化し て存在している状態をいう。

後工程の需要に従い引き取りが行われると, ワー クは在庫状態から後工程へ移動し, かんばんは補充

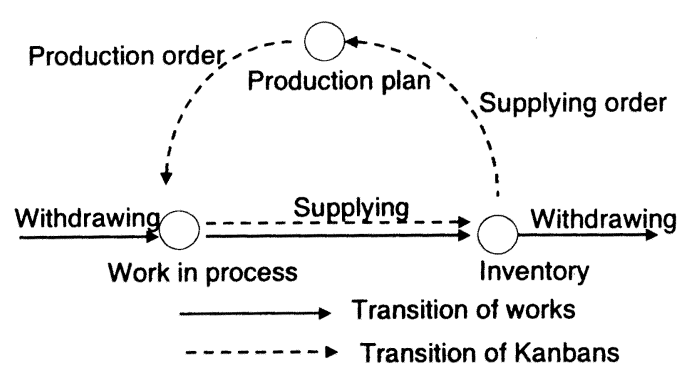

Fig.1 Operation model of Kanban

指示の情報となり, 生産計画の状態へ遷移する.

2) 生産計画

かんばんが, 生産指示を行うためにかんばん単独 で存在している状態をいう。

生産指示先に対してかんばんが，生産ロットサイ ズまでまとまると生産指示情報となり, 仕掛りの状 態に遷移する.

3) 仕掛り

仕掛り中ワークとかんばんが，一体化して存在し ている状態をいう。

必要となる部品を前工程の在庫から引き取り, ワ 一ク完成に必要な時間を経過後, ワークは完成品と なりかんばんと共に在庫補充のため在庫状態へと遷 移する.

2・3 かんばん故数決定上の同照 かんばんは， 図 1 に示される三つの状態を遷移するかんばんサイ クルをある時間を経て循環することとなる.

かんばんが, このかんばんサイクルを一周回る時 間（かんばんのリードタイム）の間の需要量に対し 欠品を発生させないためには, 在庫量, 仕掛量, 生 産計画数の総和が, この需要量を賄える必要がある. すなわち, かんばんのリードタイムあたりの需要 量に相当するかんばん枚数をこのかんばんサイクル の系に存在させることにより, 過鄱在庫も欠品もな く生産活動をコントロールすることができる(7).

しかし, 現実には以下のようなバラツキが原因で かんばん枚数は容易には決まらない.

図2にかんばんリードタイムのバラツキを発生さ せる要因を示す.

1) 単一の品種でのかんばんリードタイムのバラツキ 在庫の状態から, かんばんが外れ, 補充指示として 生産計画の状態になるまでの受け渡すタイミングが, 定時刻, 一定の時間間隔で決められている場合が多 


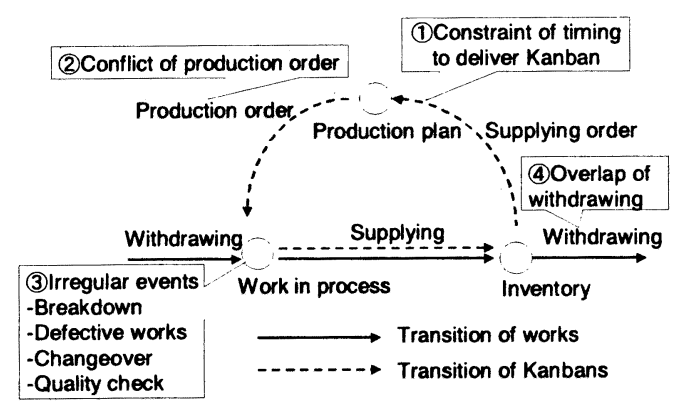

Fig.2 Factors causing the variance of the Kanban lead time

く, かんばん 1 枚 1 枚にとってみるとそのタイミング に依存した遅れ時間にバラツキがある.（図2の(1)）

仕掛りの状態でも生産設備の故障や不良の発生, 品 質確認などの非定常的な時間の発生により仕掛りの所 要時間のバラツキが生じる.（図2の(3)

2）多品種でのかんばんリードタイムのバラツキ かんばん枚数が生産ロットサイズに達し, 生産指示 を出す場合, その前に出された生産指示が未だ消化さ れていなかったり, 偶然同時に複数の品種が生産ロッ トサイズに達したりした場合, 生産指示が競合し,い ずれかの品種が仕掛かり待ちとなり滞留する場合が有 る. それは, 品種数, 生産ロットサイズに依存してバ ラツキを発生する。（図2の(2)

3）多段階生産システムのかんばんリードタイムの バラツキと引き取りのバラツキ

図3に多段階生産システムの形態例を示す。多段 階生産システムでは, かんばんサイクルが連鎖でつ ながっていく中, 後工程では別の品種だが, 前工程 では共通の品種となる場合もある. その結果, 各か んばんサイクル間での引き取りの量, タイミングの バラツキが増幅したり, 逆に減少したりと非常に予 測が難しくなる.（図2の(4)）

また, 図3の（b）のような場合, 生産ライン 2 と生産ライン 3 がつながったものとして考えられる ので, 非定常的な時間の発生確率が増大し, 仕掛り 状態でのバラツキが増幅される.

\section{$2 \cdot 4$ 生産ロットサイスの決定上の间成 一般} に生産ロットサイズを大きくすると, 品種切り替え頻 度が減るため, 需要に対して久品を起こす可能性があ る. その可能性を少なくするために, 在庫量は增える 傾向にある. 一方, 品種切り替えのロスは減少し, 品 種切り替えコストは低減する。

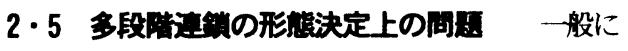
生産リードタイムを長くすると, 需要に対して生産し て供給する応答性が悪くなり, 供給の遅れによる欠品 発生防止のため在庫量は增える.

多段階生産システムの中で, かんばんサイクル の連鎖のさせ方で生産リードタイムが変化する. 例 えば, 図3の（a）と（b）は同じ生産ラインの構 成であるが，（a）は1本ずつを別のラインとして 見て生産指示を出すが，（b）は2本を一連のライ ンとしてみなして生産指示を出しており, 生産制御 という視点からは生産のリードタイムが異なってく る.

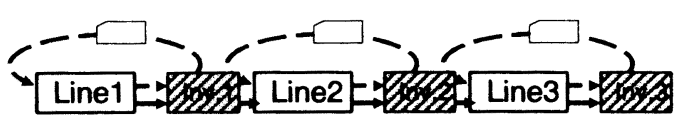

(a) Each line is individual

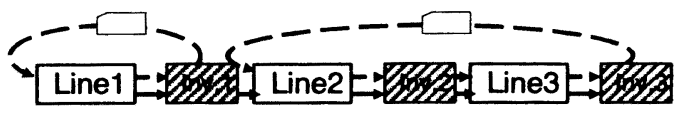

(b) Line 2 and Line 3 are connected

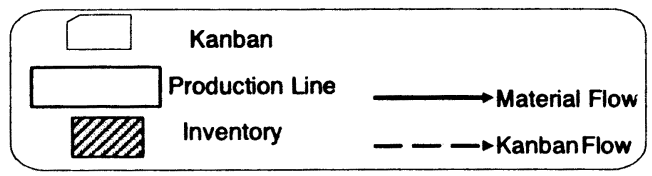

Fig.3 Structure of multi stages Kanban-production

\section{$2 \cdot 6$ システムの評価 多品種多段階かんばん} 生産システムの運用を評価する基準は, 在庫コストと 品種切り替えコストの総和で行われる.

これらの関係は, トレードオフの関係になる.

1) 在庫コスト

在庫置き場にワークが滞留すること, あるいは欠 品することに伴い発生するコストをいう. 帯留側で は在庫品の金利, 管理費用, 置き場の面積費用など, 欠品側では, 機会損失, 賠償などがあげられる.

2）品種切り替えコスト

生産ラインで品種切り替えに伴い発生するコスト をいう. 品種切り替え時の設備停止時間や作業者の 休止および作業時間による損失などがあげられる.

\section{3 シミュレーションを用いた かんばん生産システムの团用手法}

かんばん生産システムの運用を適切に行うために は, 2·3で整理したバラツキを考虑して, 運用条件 であるかんばん枚数, 生産ロットサイズ, 多段階連 鎖の形態を在庫コストと品種切り替えコストの総和 
が最も小さくなるよう決定しなければならない。し かし, 実際の生産現場では, 全てのバラツキを数理 的に求め, かんばんリードタイムを推定し運用条件 を決定していくことは実行上極めて困難である。

そこで, 本研究では $2 \cdot 3$ で上げたバラツキについ て離散系シミュレーション技術を活用して再現し, 適 切な運用条件を実験的に求めるかんばん方式の運用手 法を提案する.

\section{3・1 百用手法 運用手法のステップを図 4 に} 示す.

Step1 で対象とする生産システムのシミュレーシ ヨンモデルを作成し, 多段階連鎖の形態を設定し, Step2で生産ロットサイズ, Step3でかんばん枚数は 過㮃に与えてシミュレーションを実行する.

Step4のシミュレーション実行結果から, 品種毎 の在庫推移を求め, Setp5 で最小在庫量までの常に 滞留している余剩在庫量を確認する. Step6で余剩 在庫に相当するかんばん枚数だけを余剩かんばんと して初期に設定したかんばん枚数から差し引き，必 要かんばん枚数を求める.

Step7で在庫量から余剩在庫量を差し引く. Step8 で, 在庫が必要かんばん枚数で運用された条件にお ける在庫量となり, そこから平均在庫量を求め, 同 時に, 品種切り替え時間をシミュレーション実行結 果から求める. Step9で在庫費用之品種切り替え費 用の評価を行う.

Step10 で候補案比較を行い, かんばん枚数, 生産 ロットサイズ，多段階連鎖の形態の運用条件を決める.

\section{3・2 提葢手法の运用的提案した手法の適用} 検討例を以下に示す. シミュレーションには，多段階 連鎖のかんばんの流動のモデをパラメー夕によって 設定できるシミュレータ(たを用いている。本シミュレ 一夕は, GPSSによって開発されている。

\section{3・2・1 对象生産システム 図5，表 1 に対象} となる生産システムを示す.

在庫 2からの引き取りは時間当たり 6回で, 1 回 あたりの引き取り量は, 平均値の 4分の 1 の標準偏 差で, 正規分布に従いばらつくものとした.

Stepl: :生産システムのモデル化

表 1 の生産システムの条件と図 5 に示すラインの 前後関係を明確にしてシミュレーションモテルを作 成する。本計算例では, 図6のように開発したシミ ユレータでパラメータを指定してモデを構成した。
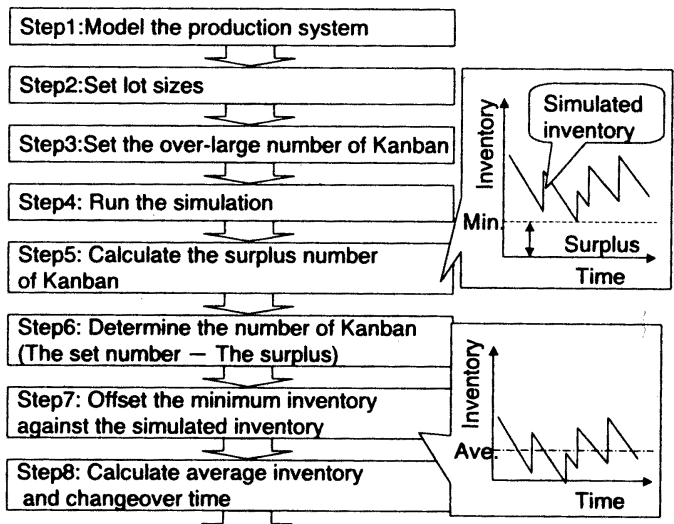

Step9: Total Inventory cost
and changeover cost

Step10: Compare the alternatives

Fig.4 Method to design and improve Kanban system

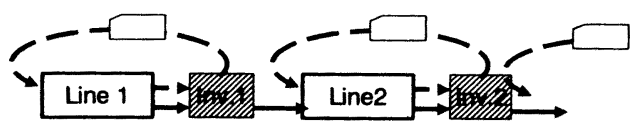

Fig.5 Sample of Production System

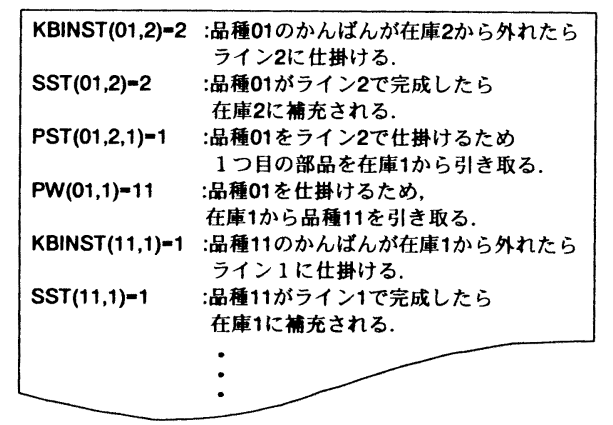

Fig.6Sample of parameters of simulator

Tablel Condition of Production System

\begin{tabular}{|c|c|c|c|c|c|c|c|c|}
\hline & \multicolumn{3}{|c|}{ Line 1} & \multicolumn{5}{|c|}{ Line2 } \\
\hline Cycle Time(s) & \multicolumn{3}{|c|}{10} & \multicolumn{5}{|c|}{10} \\
\hline Lead Timers) & \multicolumn{3}{|c|}{600} & \multicolumn{5}{|c|}{200} \\
\hline Changeover Time(s) & \multicolumn{3}{|c|}{100} & \multicolumn{5}{|c|}{10} \\
\hline Product Type & 11 & 12 & 13 & 01 & 02 & 03 & & 05 \\
\hline Kanban Capacity(pieces/Kanbar & 10 & 10 & 10 & 2 & 2 & 2 & 2 & \\
\hline Part for & 01,02 & 03,04 & 05 & \multicolumn{5}{|c|}{ - } \\
\hline Withdrawing Volume(pieces $/ \mathrm{h}$ ) & 90 & 180 & 60 & 60 & 30 & 150 & 30 & 60 \\
\hline
\end{tabular}

Step2: ロットサイズの設定

品種 01 から 05 まではロットサイズを 10 個（か んばん 5 枚）に, 品種 11，12 は100個（かんばん 10 枚），13 は 200 個（かんばん 20 枚）に設定する. 
Step3:過剩なかんばん枚数の設定

品種 01 から 13 まで, 全ての品種について 100 枚の かんばん枚数を与え，それを初期在庫として在庫 1 , 在庫 2 に設定する。

Step4:シミュレーションの実行

シミュレーション時間として20時間分を実行. 実行結果として得られる在庫の推移を品種 12 の例 で図 7 に示す。初期在庫のかんばん 100 枚分から, 時間とともに減少し，最初の 6000 秒あたりまでは 過渡状態で一方的に減少している. その後, 定常状 態になり, ある範囲内で在庫量が推移している.

Step5 : 過剩在庫の計算

図7の例では, かんばん 71 枚分の在庫が常に滞 留しており, この分が過剩であると判断できる.

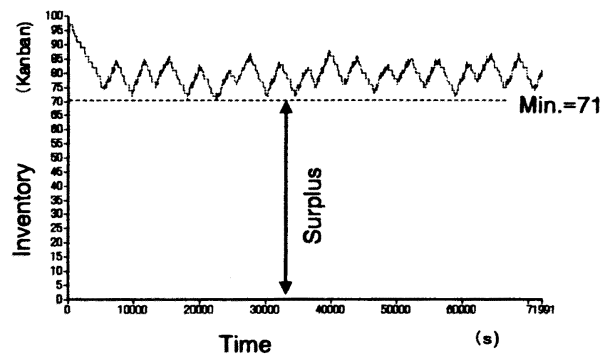

Fig.7 Simulation result of inventary of type 12

Step6:必要かんばん枚数の決定

（初期かんばん枚数－過剩在庫分のかんばん枚 数)で計算し，図7の例では，29枚である.

Step7 : 在庫量のオフセット処理

過剩在庫であるかんばん 71 枚分をオフセットす る. オフセットした結果を図8に示す.

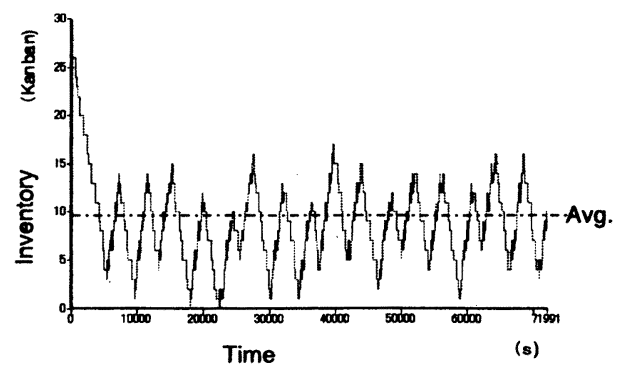

Fig.8 Offset result of inventary of type 12

Step8: 平均在庫量と品種切り替え時間の計算

オフセットされた結果から, 定常状態後の平均在 庫量が求める. 品種 12 の例では, 89 枚分である.
同様に品種 01 は 5.7 枚, 品種 02 は 5.4 枚, 品種 03 は 15.7 枚, 品種 04 は 6.1 枚, 品種 05 は 7.9 枚, 品種 11 は 5.9 枚, 品種 13 は 6.3 枚と求まる.

またライン 1 , ライン 2 の品種切り替え時間を求 める. 今回の例では, 定常状態になった後の総品種 切り替え時間は，それぞれ 4300 秒，4010 秒となり， 1 時間当たり 235 秒，219秒になる.

Step9: 在庫と品種切り替えの全体コストの計算

平均在庫量と品種番切り替え時間を所定のコスト 換算ルールに従い計算し, 全体コストを求める.

Step10: 他の代替案との比較

Step1 からStep10までの手順を綝り返し，最善の かんばん運用条件を決定する.

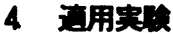

開発した手法を用いて実際の冷鈙部品工場のかんば ん方式運用条件の検討を行った. 事例を図 9 に示す.

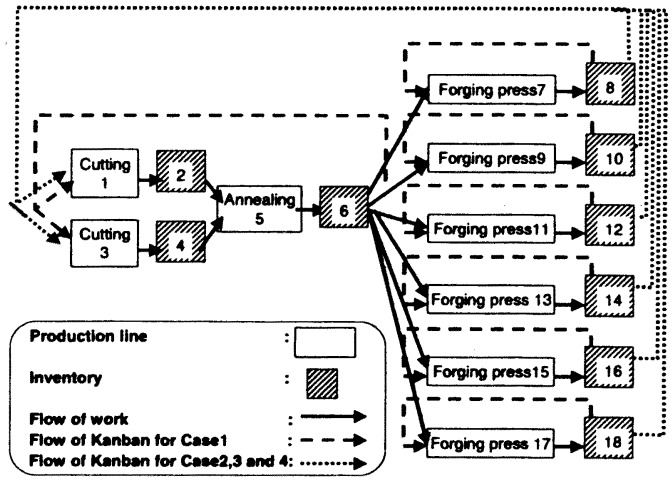

Fig.9 Cold forging shop floar for test case

18 種の品種を流動する工場で, 2 本の切断ライン, 1本のアニーリングライン，6本の泠鍛プレスライン から構成される. 切断ラインでは，品種切り替え時間 が 10 分〜30 分, 冷鍜プレスラインでは 60 分〜300分 かかる. 本ラインは，多品種多段階かんばん生産シス テムの要素を含んだ典型的な一例である.

この工場を対象に，4ケースのかんばんの運用を検 討した. ケース1は，冷鍜プスラインのれぞれの 在庫から完成品が引き取られると, 冷鉎プレスライン の先頭に生産指示が送られ，かんばん枚数が所定の口 ットサイズになると仕掛けられる．仕掛かりに当たつ ては, 必要なアニーリングライン完成品を引き取り使 用する. アニーリングラインでは, 完成品が引き取ら れると，その数に従って 2 本の切断ライン先頭に生産 
指示か割り振られて送られる. 所定のロットサイズに なると切断ラインに仕掛けられる.

ケース2は, かんばんの流れを冷鍛プレスラインの 完成品が引き取られると直接切断ラインの先頭に持つ て行き，大きな一つのかんばんサイクルとして運用す る. ケース 3 は, ケース 2 を同じかんばんサイクルを

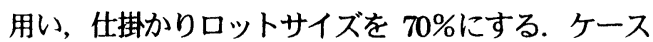

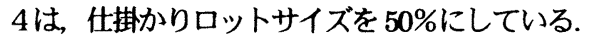

これらについて，提案する運用手法を適用した結果 を図10から図12に示す。なお,ここでは，比較のた めに正規化してグラフに示している。Step6 で, ま゙ず 対象工場をかんばん方式で品無く運用するのに最小 限必要なかんばん枚数を求めた. ケース $1: 720$ 枚, ケース $2: 577$ 枚, ケース $3: 410$ 枚, ケース $4: 377$ 枚となった.

Step8 で求めた平均在庫量を 4 つの代替案で比較し たものを図 10 に，品種切り替え時間を比較したもの を図 11 に示す。対象工場では，図10に示すように, かんばんの流れを大きなサイクルに変えたケース 2 で は在庫が減り，ロットサイズを小さくしたケース 3 , ケース 4 ではさらに在庫が減っている. 一方, 図 11 に示すようにケース1よりケース 2 では段取り時間が 減つているが，ロットサイズを小さくしたケース 3 , ケース4では，段取り時間が增えている.

Step9 で, 以上の結果をコスト換算し, Step10 で 4 つの代替案の在庫コストと品種切り替えコストの総和 を比较した結果を図 12 に示す。この例においては, 在庫量も段取り時間も少ないケース 2 が最小であり, 最も有効なかんばんの運用条件であると判断できる.

ケース 2 の結果に基づき, 実際の対象工場を最小 のかんばん枚数て実行して, 生産に問題が生じないこ とを確認し,この手法の有効性を確認した.

\section{5 落}

多品種多段階かんばん方式の設計およひ改善活動を 行っていく上で, 自らの考えた運用条件の良し悪しを 効率的に判断することを支援するシミュレーションを 活用したかんばん運用手法を提案した.

本手法では，運用条件として，あらかじめ過剩な かんばん枚数を与えてシミュレーションを実行し. 結 果の余剩在庫から, 久品無く運用するのに最小限必要 なかんばん枚数を求める方法を取ることで, かんばん 方式で運用される生産システム内の在庫量を容易に求 めることができる. そして, その在庫量と品種切り替
えの時間から運用条件に依存する総コストを導き運用 条件決定の意思判断が行える.

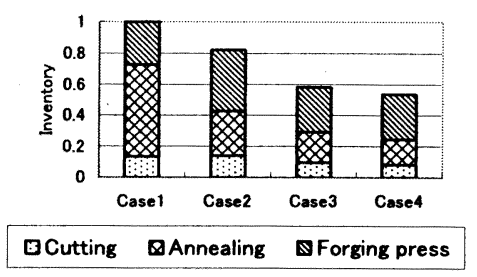

Fig.10Imventary

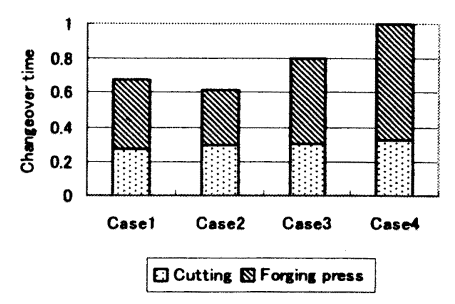

Fig.11 Changeover Trme

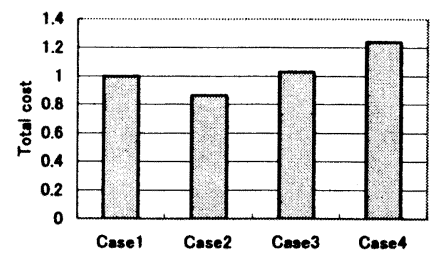

Fig.12 Comparisan amang four cases

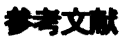

(1) Hung C.C. and Kusiak A, Overview of Kanban systems, Int J. Computer Integrated Manufacturing, 93, (1996), 169189

(2) Akturk M.S., and Erhun F., An overview of design and operational issues of kanban systems, Int. J. PROD RES., 3717,(1999),3859-3881

（3）高栖勝彦・ 中村信人, 日本経営工学会誌，No.476 (1997), 403-411

（4）楖川佳也・他 2名, 日本経営工学会誌 №.43-1（1992）, $1-5$

（5）村木孝犝・平川保博, 日本経営工学会誌，No.491 (1998) ,31-35

(6) Mitsuyuki, K, 35 ${ }^{\text {h }}$ CIRP-ISMS (2002) ,5965

（7）門田安弘，トヨ夕生産方式の新展開，(1983)，日本能率 協会 